University for Business and Technology in Kosovo

UBT Knowledge Center

UBT International Conference

2014 UBT International Conference

Nov 8th, 2:45 PM - 3:00 PM

\title{
Urban transformation in see countries
}

\author{
Binak Beqaj \\ University for Business and Technology, bbeqaj@ubt-uni.net \\ Vlora Aliu \\ University for Business and Technology, vlora.aliu@ubt-uni.net
}

Follow this and additional works at: https://knowledgecenter.ubt-uni.net/conference

Part of the Architecture Commons

\section{Recommended Citation}

Beqaj, Binak and Aliu, Vlora, "Urban transformation in see countries" (2014). UBT International

Conference. 6.

https://knowledgecenter.ubt-uni.net/conference/2014/all-events/6

This Event is brought to you for free and open access by the Publication and Journals at UBT Knowledge Center. It has been accepted for inclusion in UBT International Conference by an authorized administrator of UBT Knowledge Center. For more information, please contact knowledge.center@ubt-uni.net. 


\title{
Urban transformation in see countries
}

\author{
Binak Beqaj ${ }^{1}$, Vlora Aliu ${ }^{2}$ \\ ${ }^{12}$ University for Business and Technology, Prishtina, Kosova \\ bbeqaj@ubt-uni.net ${ }^{1}$,vlora.aliu@ubt-uni.net ${ }^{2}$
}

\begin{abstract}
Urban developments in SEE Countries are followed by development analogies on: rapid growth of urban population, level of economic development, planning (dis) continuity, relationships between public/private partnerity, standardization of qualitative urban life and urban expansion on suburb areas.

The content of the research is focused on City Capitals of those Countries and their actual urban dynamics. Urban planning concepts, urban development challenges and adequate institutional mechanisms related to development, are some of the issues with strong reflections on qualitative and integrated urban planning from SEE Countries.

Key words: urban planning, rapid growth, partnerity, quality, standardization, dynamics, development, mechanisms, integration.
\end{abstract}

\section{Introduction}

"Theory ...does not flow above everyday life in a detached way it comes from some place, and it is the responsibility of analysis to return it there".

Urban Theory and urban Experience-Simon Parker

The question raised about the specific urban topics under urban development nowadays, in SEE countries is:

-Is the process integrative and in correlation with citizens expectations?

\subsection{Analogy of urban developments and challenges in SEE Countries}

The citizens need for more urban space with adequate infrastructure towards development perspective for improving quality of life, is followed by challenges :

- Economic and political changes;

- Rapid growth of population;

- Continuous urban planning process;

- Public and private partnership relations;

- Needed space and ownership status.

In some cases urban policy didn't follow urban dynamics or sometime policy was too much involved reducing integrated development framework.

\section{Some of the urban dynamics in capital cities of CEE Countries}

\subsection{Tirana-Albania \& Prishtina-Kosova}

Tirana, with population of 422,000 (2011) inhabitants, based on huge migration of population. Growth of population was $7 \%$ per year. The urban space of Tirana includes $260 \mathrm{~km} / 2$, twice more in comparison with year 1990. Most of urban areas are characterized with informal development and illegal constructions. 
Prishtina, with population of 200,000 inhabitants (2012), with continuous rapid growth from the year 2000 (after the war). The planned urban area for Prishtina was more than $50 \mathrm{~km} / 2$. Most of urban areas are characterized with informal development and illegal constructions.
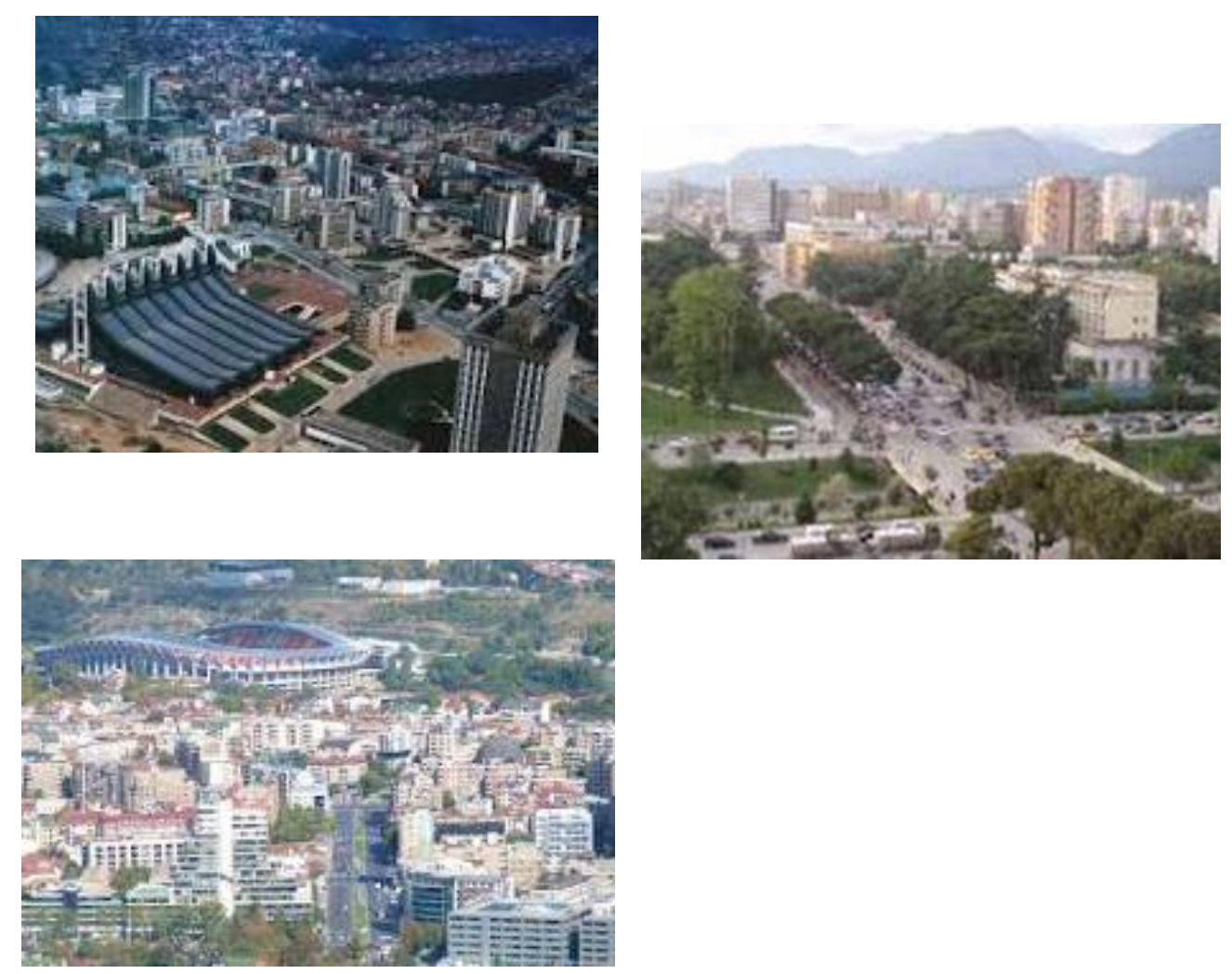

Fig.1. View from Tirana and Prishtina, Shkupi-Macedonia; Lublana-Slovenia \& Zagreb-Croatia

Shkupi, with population of 531,000 inhabitants (2011), based on migration of population it was a systemic growth of city. The urban space of Shkupi includes $471 \mathrm{~km} / 2$. Most of urban areas are characterized with informal development and illegal constructions and its center with political urban development.

Zagreb, with population of 792,000 inhabitants (2011), based on migration of population it was a systemic growth of the city. The urban space of Zagreb includes $641 \mathrm{~km} / 2$. Most of urban areas are characterized with formal but also informal developments.

With population of 272,000 (2010) inhabitants. The urban space of Ljublana includes $168 \mathrm{~km} / 2$. Most of urban areas are characterized with planned development and systemic development 



Fig.2. View from Shkupi, Lublana and Zagreb

\section{Urban Challenges from capital cities of CEE Countries}

\subsection{Illegal constructions \& informal settlements}

Approximately $1 / 3$ of buildings in urban areas of SEEC are without adequate urban planning and infrastructure, all over informal urban areas or as illegal constructions in existing urban areas. Experience shows that: legalization, penalties and even demolition; has not completely stopped informal development. But, also:dis-continual urban planning or lack of urban planning; has motivated chaotically urban developments

\subsection{Changing density through urban regeneration}

The figure below shows a schematic representation of the transformation from low density informal development into a high density formal development. The owners of the original houses in the informal development are resettled in the new apartments and are compensated in different models. 


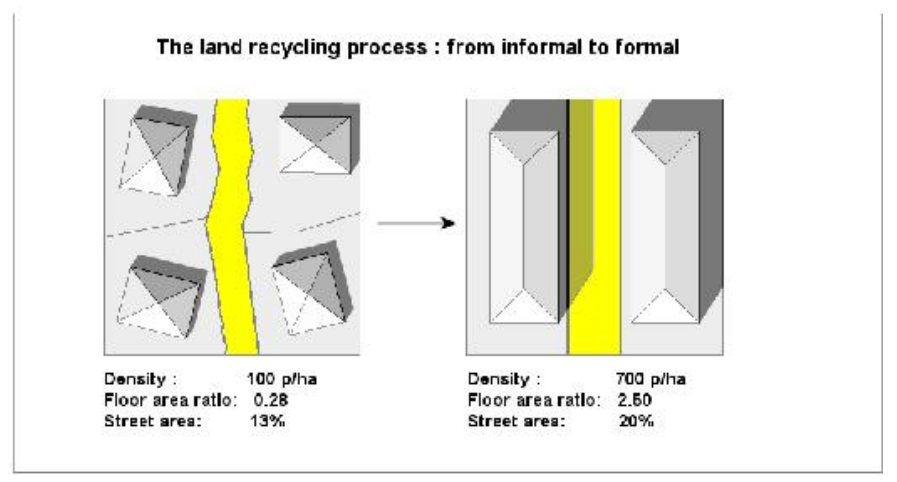

Fig.3. Density and urban regeneration

\subsection{Urban planning and society segregation}

From the experience, urban segregation is to be considered as main urban threat, there are different types of segregation identified specifically from cases in SEE Countries:

- Social segregation (education, health, employment and wellbeing)

- Infrastructural segregation (public infrastructure, services and transport)

- Spatial segregation(positioning, environment, energy efficiency )

- Segregation on decision making (equity, comprehensiveness)

Transparency, involvement and cohesion in urban planning process are tools for avoiding urban segregation.

\subsection{Weaknesses, in urban planning process from city-capitals of SEE Countries}

Analyzing urban development from study cases of SEE Countries, it comes that there are differences and common identities:

- Lack of adequate municipal urban infrastructure related to: parking spaces,

- public toilets, schools, greenery, clinics, recreation areas, parking spaces;

- Not adequate capacities for: treatment of waste management, neighborhood safety, unclearity legal rights on land and land use;

- Lack of budget for extra costs for environmental improvements in existing or new urban areas;

- Not adequate related decision making process and lack of reliable spatial information;

- Lack of adequate treatment for: corruption, transparency, land management issues, social segregation, and participation of stakeholders in decision making process, state revenue through: loss of property transaction fees, permit, fees, and property taxation.

\section{National urban planning-structures}

As presented on Figures below, there are different organizational structures at National level in SEE Countries regarding urban planning. Mostly those Countries have similar structure (probably harmonized with EU, through integration process), but, still differences on naming those bodies. There are three levels:

- Parliamentary body-Council

- Governmental body-Ministry

- $\quad$ Professional body-Institute 

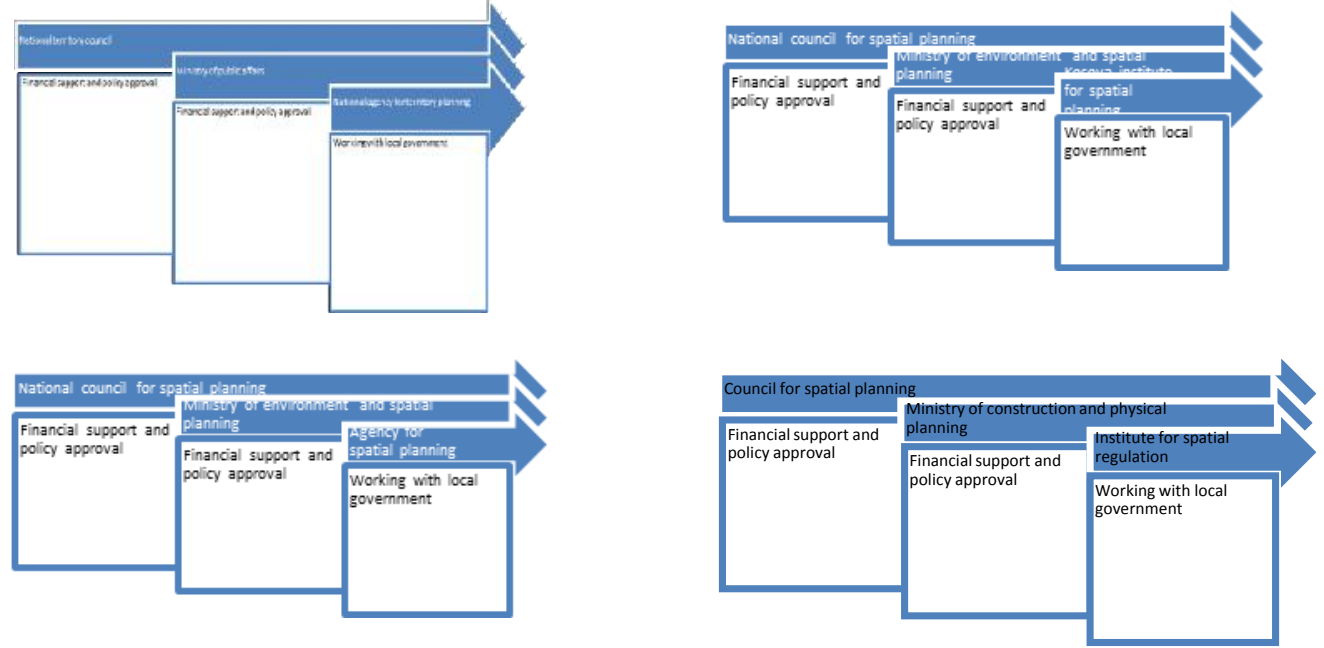

Fig. 4. National urban planning structures in: Albania, Kosova, Macedonia and Croatia

\section{Policy and urban governance related to national institutions in SEE Countries}

During last decade, urban planning policy and urban governance in SEE countries, was characterized by:

- Reconstruction and urban transformation of existing urban areas

- Designing but not implementing integrated urban modules

- Limitations on implementing new ideas

- Involving but not recognizing enough interests from partners

- Developing, but not still defining clarity in terms of property rights

- Building up the capacity of all institutional levels in at least the following fields: understanding and application the legal framework, principles of sustainable urban development, land economics, finance and land management, transparency and decision making

\section{Urban transformation-study cases from SEE Capitals}

Urban revitalization-Zagreb-Sopnica new residential area for 10.000 inhabitants, good example of space transformation from farm to integrated urban area with all qualitative urban parameters included (density, traffic, greenery...). 




Fig.5. Urban Planning of the District Sopnica-Jelkovec (Zagreb)

\subsection{Transformation from squatter settlement to suburb neighborhood}

-Tirana-Bathore informal area from 1990, problem was created because of huge migration of population to Tirana during transformation political processes. Transforming this informal urban area into urban through urban regeneration and rehabilitation it was not easy task of cooperation between national and international urban planning mechanisms.
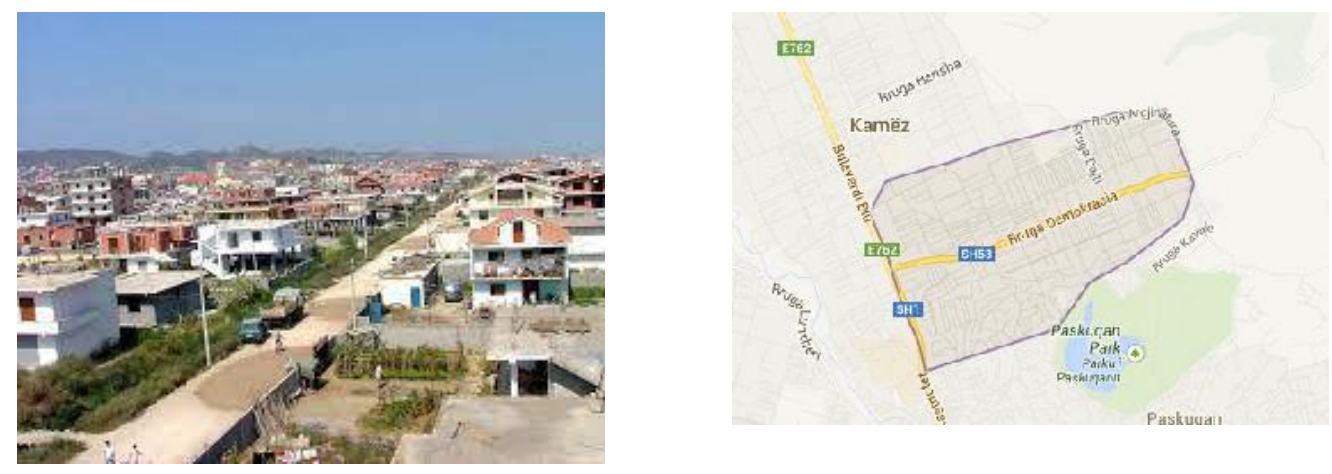

Fig.7. Urban rehabilitation and regeneratio of informal settlement Bathore (Tirana)

\subsection{Social housing development- Nove Fuzhine (Ljublana), from 1995}

This area of 69 ha, was developed by urban planning for 13433 inhabitants, with domination of social housing, based on evident needs of inhabitants. Average number of flats per building is 72 , while average flat area is $65 \mathrm{~m} / 2$. This was well designed area for that time, but, nowadays is becoming a problem for authorities because of social segregation happened there and difficulties to re-integrate this part in city area.

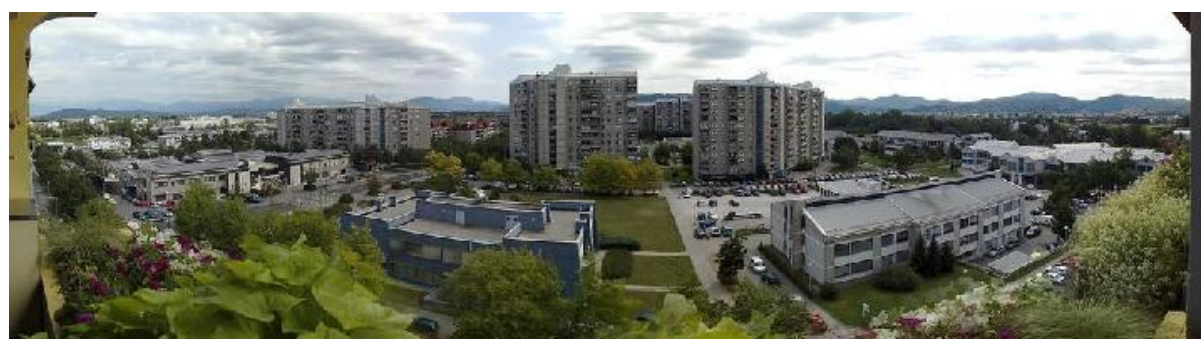


Fig.8. Social housing Nove Fuzhine (Ljublana)

"International village", Veternik- Prishtina individual housing-new suburb as isolated island

New urban areas with high level of urb-architectural contemporary values, but unfortunately not followed by adequate infrastructure and urban surrounding, so, they are more to be considered as multiply urban islands in periphery of urban area of Prishtina, because this trend is more as part of urban segregation.
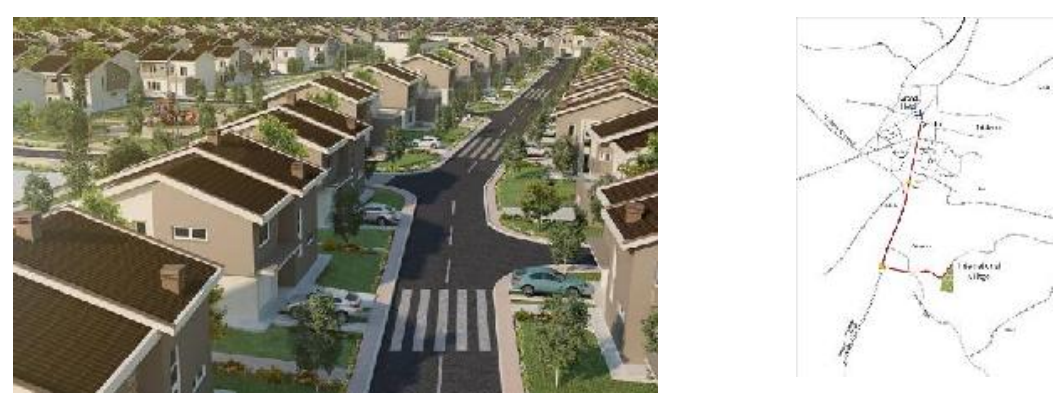

Fig.9. International village, Veternik (Prishtina)

\subsection{Center of the city-Shkup-political influence on new identity}

Last year's architectural/urban developments are crucially influenced by political ideology of Macedonians, avoiding originality of the city structure based on multi-national contents. Authorities, through political urban muzealisation and improvisation are more considering segregation than integration and continual urban development.

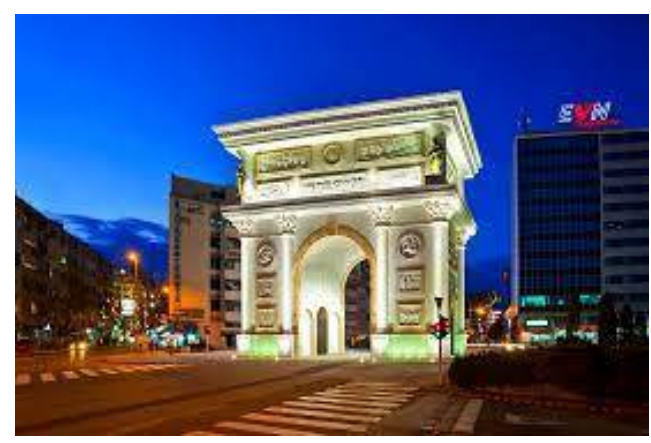

Fig.10. Partial view of the center influenced by actual policy on identity (Shkupi)

\section{Conclusions}

Housing, is still one of the main urban challenge, characterized by: poor quality, high maintenance costs, high density, social housing and segregation. 
Urban identity, already lost: problems with destination use of the space, lack of interrelation between different urban units especially with center, disproportion between different physical structures and environment, discontinuity between existing and new architecture, efficient communication and traffic flow. Energy efficiency use, especially in public spaces and public functions. Also, use of building materials related to energy efficiency use.

Density is also problematic urban issue of urban development for case studies analyzed, especially this was a result of rapid growth of City capitals after transition periods, and not adequate institutional urban governance through urban regeneration of existing areas or development of new urban areas.

Traffic and transport, actually characterized with motorization, dominated by use of personal cars (is around $65 \%-70 \%$ ) with the aim to be transformed on an ecological traffic (to be around $35 \%$ ), pedestrians and cycle traffic paths.

Institutional urban structures are well designed and structured (identity based on EU guidelines), but, still not proactive towards urban developments as leading mechanisms (limited as lack of adequate professional staff and legislative infrastructure).

Finally, integrative processes should be harmonized with intensive urban dynamics towards qualitative life in urban areas.

\section{References}

1. EU, transitional cooperation programs 2007-2013 for SEE Countries, EU Commission (2007)

2. Fighting poverty in an urban world, SIDA policy, SIDA (2006)

3. More urban, less poor, an introduction to urban development and management, Tannerfeldt \&Ljing (2006)

4. The urban planning process, NALAS (2010)

5. The legislation and analysis of the implementation of spatial and urban planning in Albania,Kosovo,Macedonia,Moldava and Turkey as compares to the case od Denmark, NALAS (2009)

6. Urban management, B Beqaj (2007)

7. EU southern neighborhood, ACG (2014)

8. The urban development network programme, URBACT II 2007-2013, EU Commission (2007) 